\title{
Addition of azithromycin to the routine pre-cesarean prophylaxisagainst infection, effective or not?
}

Ahmed A. El-Zayadi', MD,

Rafik Ibrahim Barakat', MD, Layla Abd El Hamid El Boghdady'. MD,

Marwa Ahmed El Shafey², MSc,

Shereen M. Mohammed', MD

'Department of Obstetrics and

Gynecology, Mansoura University,

Mansoura, Egypt

${ }^{2}$ Department of Obstetrics and Gynecology, MitGhamr health insurance hospital
Corresponding author:

Ahmed A. El-Zayadi

Department of Obstetrics and

Gynecology, Mansoura University

Hospitals, Elgomhouria St.,

Mansoura City 35111, Dakahlia,

Egypt

Tel +20502946830/40

Email: ahmedelzayadi@yahoo.

com

\section{$\underline{\text { Abstract }}$}

Purpose: There is debatable data regarding the addition of azithromycin to the routine antibiotic prophylaxis of post-cesarean section (CS) infection. In this work, we tried to evaluate its potential benefit to protect against both post-cesarean maternal and fetalinfections.

Methods: The study included 230 women who were intended to have selective CS at Mansoura university hospital. They were randomly subdivided into115 women that received azithromycin plus standard cephalosporin and another115 women that received standard cephalosporin alone. The main outcome is evaluation of post-cesarean section infection as endometritis, wound sepsis, etc... across the puerperal period.

Results: In comparison between the test group and the control group, there was significant reduction of re-admission during puerperium $(0 \%$ vs $6.5 \%, \mathrm{p}=0.01)$. Endometritis manifestations were significantly reduced, including: puerperal Fever $>38 \mathrm{OC}$ ( $4.3 \%$ versus $15.2 \%$ ), uterine tenderness $(3.2 \%$ versus $11.9 \%)$, abdominal pain $(1.1 \%$ versus $14.1 \%)$, offensive vaginal discharge $(2.1 \%$ versus $13 \%)$ and purulent drainage from uterus $(2.1 \%$ versus $9.8 \%)$. Wound infection manifestations were significantly reduced, including; erythema around incision ( $2.1 \%$ versus 8.7 ), induration around incision (3.2 versus $12 \%)$ and purulent discharge from incision site (1.1\% versus $9.8 \%)$. Also, the need for further antibiotic during puerperium was significantly reduced (3.2\% versus $11.9 \%$ ). There was no significant difference between the 2 groups regarding neonatal outcomes.

Conclusion: Azithromycin plus the standard cephalosporin administered to women in selective CS reduces maternal infections and maternal episodes of fever, with no clear benefit on the neonatal outcome.

Keywords: Azithromycin, Post-cesarean section infection

\section{INTRODUCTION}

Cesarean delivery is considered as one of the major procedures for saving both maternal and fetal lives. The incidence of cesarean deliveries, both repeat and primary, has risen lately in Egypt to be doubled between 2005 and 2014, and reach according to Egypt demographic and health survey to $52 \%$ of all deliveries. Egypt now is in the third rank worldwide between countries with the highest rates of caesarean section after Dominican Republic and Brazil(1).

Post-partum infection globally represent one of the leading direct causes ofmaternal morbidity and mortality which in turn elongate 
the length of hospital stay and add burden to the healthcare costs.Caesarean delivery is counted as one of the major risk factors for postpartum infection (2). Compared to planned vaginal delivery, women who underwent elective caesarean section had double to triple risk to be re-hospitalised for wound complications and/or infections (3).

Surgical site infection (SSI) and endometritis are the main two sub-groups of the post-caesarean section infections. SSI refers to skin and subcutaneous infection at the site of the incision. Endometritisrefers to infection of the endometriallining of the uterus with/without its wall (4).

The American College of Obstetricians andGynecologists (ACOG) recommendations 2011 endorsed theuseof an antimicrobial prophylaxis within 60 minutes from the onset of the caesarean incision and to be as soon as possible in cases of unscheduled caesarean deliveries. The appropriateantimicrobial coverage can be effectively provided bythe first generationcephalosporin or aminoglycosides combined with clindamycin in cases of hypersensitivity tocephalosporins(5). According to Cochrane review 2014,penicillinsare equivalent tocephalosporinsas regard to their prophylactic activity (6).

A single dose of one gram ofcefazolin provides the adequate and the broad spectrum antimicrobial coverage for normal and overweight women.However, the doseshould be adjustedfor more obese women(5).

Adding azithromycin to the routine pre-cesarean cephalosporin prophylaxis against infection may add great benefits to ladies delivering by CS. Having a longer half-life (68 hours) with its higher tissue concentrations and lesstransplacental passage compared with other antibiotics plus its antimicrobial activity against both aerobes and anaerobes, as well as Ureaplasmas, all making azithromycin a valuable addition to the prophylaxis against the post caesarean section infections. It significantly decreases the risk ofendometritisand SSI when added to the routine pre-cesarean cephalosporin prophylaxis (7\&8).

\section{Material and Method}

\section{Study design}

This study was carried out as a prospective randomized non-blinded controlled trial.

\section{Study subject}

The estimated sample size is 230 patientswho were intended to have selective CS (this number including $10 \%$ increase to the estimated minimal sample size). The estimated sample size was calculated with a level of confidence of $95 \%$. Those patients were randomly subdivided into two groups: testgroup includes 115 women who received Azithromycin plus standard cephalosporin, and control group includes 115 women who received standard cephalosporin alone.

\section{Setting}

Obstetrics and gynecology department, Mansoura university hospitals (tertiary hospital), Mansoura University, Egypt.(Figure 1).

\section{Inclusion criteria}

Women $>28$ weeks viable gestation, women undergo unscheduled / selective cesareans with either labor (spontaneous or induced) or ruptured membranes.

\section{Exclusion criteria}

Vaginal delivery, elective or scheduled cesarean prior to labor or membrane rupture, known Azithromycin (or other macrolide) allergy, clinical chorioamnionitis or any other active bacterial infection (e.g. pyelonephritis, pneumonia, abscess), fetal demise or major congenital anomaly, significant liver disease, significant renal disease or on dialysis, active congestive heart failure or pulmonary edema, active diarrhea at time of delivery, and immunosuppressed patients.

\section{Drug administration}

All patients were received the standard routine cephalosporin (1gm ceftriaxone) before the surgical incision.Azithromycin (500 mg) was given concurrently with the standard cephalosporin bolus in the test group. 


\section{Outcome measures}

Endometritis and lor wound infection and lor post-cesarean infections (occurring within 4-6 weeks of delivery) defined as follows:Endometritis is the presence of two or more of the following signs with no other recognized cause: fever $>38 \mathrm{C}$, abdominal pain, uterine tenderness, or purulent drainage from uterus. Wound infection is the presence of either superficial or deep incisional surgical site infection characterized by cellulitis/erythema and induration around the incision or purulent discharge from the incision site with or without fever.Other infections include pelvic septic thrombosis, abdominal or pelvic abscess, pyelonephritis, pneumonia or maternal sepsis.

\section{Results}

In this work we tested the effect of addition of azithromycin to the standard pre-cesarean section cephalosporin prophylaxis (the test group), in comparison to the standard pre-cesarean section cephalosporin prophylaxis alone (the control group). There was no significant difference regarding the socio-demographic, obstetric data and conditions among studied groups(Table 1 and 2).

Endometritis, wound infection needed antibiotics and re-admission during puerperium were significantly reduced in the test group in comparison to the control group $(\mathrm{P}=0.006,0.02$ and 0.01 respectively) (Table 3 ).

On comparison between the 2 studied groups we found that puerperal Fever $>380 \mathrm{Oc}$, uterine tenderness, abdominal pain, offensive vaginal discharge and purulent drainage from uterus were significantly increased in the control group. Also, we found that the need for further antibiotic during puerperium was significantly increased the same group. (Figure 2, and Table 4).

On comparison between the 2 studied groups(Figure 3, and Table 5) we found that erythema around incision, induration around the incision, purulent discharge from the incision site, need for further antibiotic during puerperium and white blood cells count(WBCs) at 7th day postpartum were significantly increased in the control group receiving cephalosporin alone .

There was no significant difference regarding neo- natal outcomes between both the test and the control groups.(Table 6).

\section{Discussion}

Cesarean section (CS) has dramatically increased over the last decade in Egypt to reach up to institution based rate of $67.3 \%$ (9). Although it is considered as an important lifesaving operation for both mother and child in many situations, however, this does not omit the fact that it is one of the most important risk factor for postpartum maternal infection which can increase maternal morbidity and mortality (10). Current recommendations for antibiotic prophylaxis in cesarean delivery include the standard administration of a broad-spectrum antibiotic before the skin incision (11). Unscheduled CS represent about $60 \%$ to $70 \%$ of all caesarean deliveries and up to $12 \%$ of women undergoing selective cesarean sectiondelivery had puerperal infection when the standard pre-incision prophylaxis was used(12). These two facts point the importance of availability of more effective antibiotic regimens for protection against post CS infections.

The current study aimed to evaluate the efficacy of addition of Azithromycin with its strong antibacterial and bacteriostatic effects against atypical pathogens (13)to the standard cephalosporin (ceftiaxone) which has strong antibacterial effect against E. coli and Enterobacteriaceaein reducing the risk of post-cesarean infection compared to cephalosporin alone among women undergoing unscheduled cesarean delivery.

186 ladies undergoing unscheduled CS were included in the current study. They were subdivided into two groups, study group: included 94 subjects that received Azithromycin (500 mg) plus standard cephalosporin (ceftiaxone $1 \mathrm{gm}$ ), and control group: included 92 subjects that received standard cephalosporin (ceftiaxone $1 \mathrm{gm}$ ) alone.

There was no significant difference regarding the socio-demographic, obstetric data and conditions among studied groups (Table 1 and 2).

In our study there was significant reduction of re-admission during puerperium among the test group in comparison to the control group $(0 \%$ vs $6.5 \%, p=0.01)$. Also, all signs and symptoms of endometritis (including; puerperal Fever $>380 \mathrm{OC}$, 
uterine tenderness, abdominal pain, offensive vaginal discharge and purulent drainage from uterus) were significantly reduced among the test group in comparison to the control group. Also, all signs and symptoms of wound infection (including; erythema around incision, induration around incision, purulent discharge from incision site, need for further antibiotic during puerperium and WBCs at 7th day postpartum) were significantly reduced among the test group in comparison to the control group.

In accordance with our findings, Tita et al. found the adjunctive azithromycin prophylaxis for caesarean delivery in 1019 cases (study group) showed a significant protective effect against maternal endometritis, wound infection $(2.4 \%$ vs $6.6 \%, p<0.001)$ and serious maternal adverse events $(1.5 \%$ vs $2.9 \%, p=0.03)$ in comparison of addition of placebo in 994 control cases. This effective prophylaxis may be explained by its ability to cover againstureaplasma species, which are reported to be frequently associated with post CS infections (14).

In the same context, Ward and Duff 2016 evaluated the effect of addition of azithromycin to a first generation cephalosporin drug (cefazoline) before skin incision on prevention of postpartum endometritis in comparison to cefazoline alone after cord clamping. Although the difference in the timing of administration and the cephalosporine generation used, but their findings were consistent with ours as regard the significant protection against postpartum endometritis in azithromycin group (8).

Harper et al., 2017 and Skeith et al., 2017 tested the cost effectiveness of addition of azithromycin to the routine cephalosporin given as a prophylaxis against post-partum infections in both scheduled and non-scheduledCS. The research group found addition of azithromycin is both effective in reduction of post-partum infectious complication plus being of less cost compared with the cost of treatment of such complications (15and16).
In contrast, Johnson et al., 2019 in a retrospective study found addition of azithromycin to cephalosporines add no value in prevention of post-partum infections. Being a retrospective study and included only 100 participant making this study need further research to stand in front the growing evidence of the efficacy of addition of azithromycin to the routine prophylaxis in cases of selective $\mathrm{CS}(17)$.

In the present study, there was no significant difference between the 2 groups regarding neonatal outcomes in accordance withTita and his colleagues (14) and Ward and Duff(8).In contrast, Oluwalana and his colleagues found azithromycin administered to women in labor reduces maternal and neonatal infections as otitis and conjunctivitis probably due to the effect on colonization of Staphylococcusaureus and Streptococcus species in the newborns, because these bacteria are major causes of both conditions. This contrast in the results can be explained by the fact that Oluwalana compared administration of azithromycin in test group with giving only placebo in the control group, both were delivering vaginally(18). We recommend performance of larger trials designed to assess the effect of prophylactic use of azithromycin on severe morbidity with studies that allow doing cultures for ureaplasma and other bacteria.

\section{Ethical approval}

The study was approved by the Mansoura Faculty of Medicine Institutional Research Board (MFMIRB).

\section{Conflict of interest}

The authors declare that they have no conflict of interest.

Availability of data and material are confirmed. 


\section{References}

1. Elnakib S, Abdel-Tawab N, Orbay D, Hassanein N. Medical and non-medical reasons for cesarean section delivery in Egypt: a hospital-based retrospective study. BMC Pregnancy Childbirth. 2019;19(1): 411-415

2. Kassebaum NJ, Bertozzi-Villa A, Coggeshall MS, et al. Global, regional, and national levels and causes of maternal mortality during 1990-2013: a systematic analysis for the Global Burden of Disease Study 2013. Lancet. 2014;384(9947):980-1004.

3. Declercq E, Barger M, Cabral HJ, et al. Maternal outcomes associated with planned primary cesarean births compared with planned vaginal births. Obstet Gynecol. 2007;109(3):669-677.

4. Pierson RC, Scott NP, Briscoe KE, Haas DM. A review of post-caesarean infectious morbidity: how to prevent and treat. J ObstetGynaecol. 2018;38(5):591-597.

5. American College of Obstetricians and Gynecologists. ACOG Practice Bulletin No. 120: Use of prophylactic antibiotics in labor and delivery. Obstet Gynecol. 2011;117(6):14721483.

6. Gyte GM, Dou L, Vazquez JC.Different classes of antibiotics given to women routinely for preventing infection at caesarean section. Cochrane Database Syst Rev. 2014;2014(11):CD008726.

7. Tita AT, Hauth JC, Grimes A, Owen J, Stamm AM, Andrews WW. Decreasing incidence of postcesareanendometritis with extended-spectrum antibiotic prophylaxis. Obstet Gynecol. 2008;111(1):51-56.

8. Ward E, Duff P. A comparison of 3 antibiotic regimens for prevention of postcesarean endometritis: an historical cohort study. Am J Obstet Gynecol. 2016;214(6):751.e1-751.e7514.

9. Al Rifai RH. Trend of caesarean deliveries in Egypt and its associated factors: evidence from national surveys, 2005-2014. BMC Pregnancy Childbirth. 2017;17(1):417.
10. Halder A, Vijayselvi R, Jose R. Changing perspectives of infectious causes of maternal mortality. J Turk GerGynecol Assoc. 2015;16(4):208213.

11. Sun J, Ding M, Liu J, et al. Prophylactic administration of cefazolin prior to skin incision versus antibiotics at cord clamping in preventing postcesarean infectious morbidity: a systematic review and meta-analysis of randomized controlled trials. GynecolObstet Invest. 2013;75(3):175-178.

12. Costantine MM, Rahman M, Ghulmiyah L, et al. Timing of perioperative antibiotics for cesarean delivery: a metaanalysis. Am J Obstet Gynecol. 2008;199(3):301.e1-301.e3016.

13. Purba AKR, Setiawan D, Bathoorn E, Postma MJ, Dik JH, Friedrich AW. Prevention of Surgical Site Infections: A Systematic Review of Cost Analyses in the Use of Prophylactic Antibiotics. Front Pharmacol. 2018;9:776-781

14. Tita AT, Szychowski JM, Boggess K, et al. Adjunctive Azithromycin Prophylaxis for Cesarean Delivery. N Engl J Med. 2016;375(13):12311241.

15. Harper LM, Kilgore M, Szychowski JM, Andrews WW, Tita ATN. Economic Evaluation of Adjunctive Azithromycin Prophylaxis for Cesarean Delivery. Obstet Gynecol. 2017;130(2):328334.

16. Skeith AE, Niu B, Valent AM, Tuuli MG, Caughey AB. Adding Azithromycin to Cephalosporin for Cesarean Delivery Infection Prophylaxis: A Cost-Effectiveness Analysis. Obstet Gynecol. 2017;130(6):1279-1284.

17. Johnson C, Dagum C, Persad MD, Herrera KM, Buckley A, Garretto DJ. Does Adjunctive Azithromycin Cesarean Bundle Decrease the Risk of Maternal and Neonatal Outcomes?Obstetrics\&Gynecology. 2019; 133(5): 90S-91S.

18. Oluwalana C, Camara B, Bottomley C, et al. Azithromycin in Labor Lowers Clinical Infections in Mothers and Newborns: ADouble-Blind Trial. Pediatrics. 2017;139(2):e20162281. 
Figure 1:Consort flow of the study.
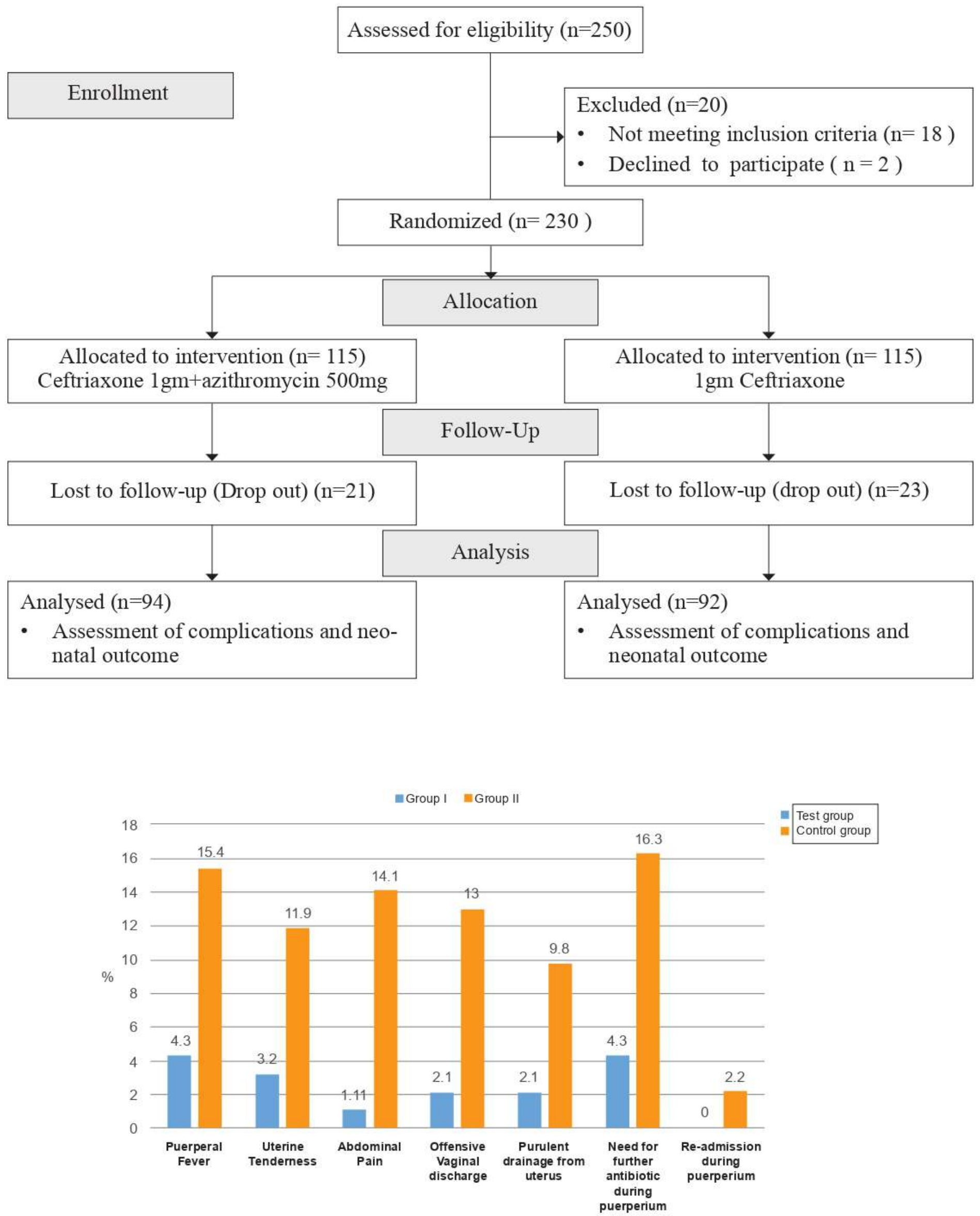
Figure 3: Wound infection distribution among studied cases

Eroup I = Group II

Test group

Control group

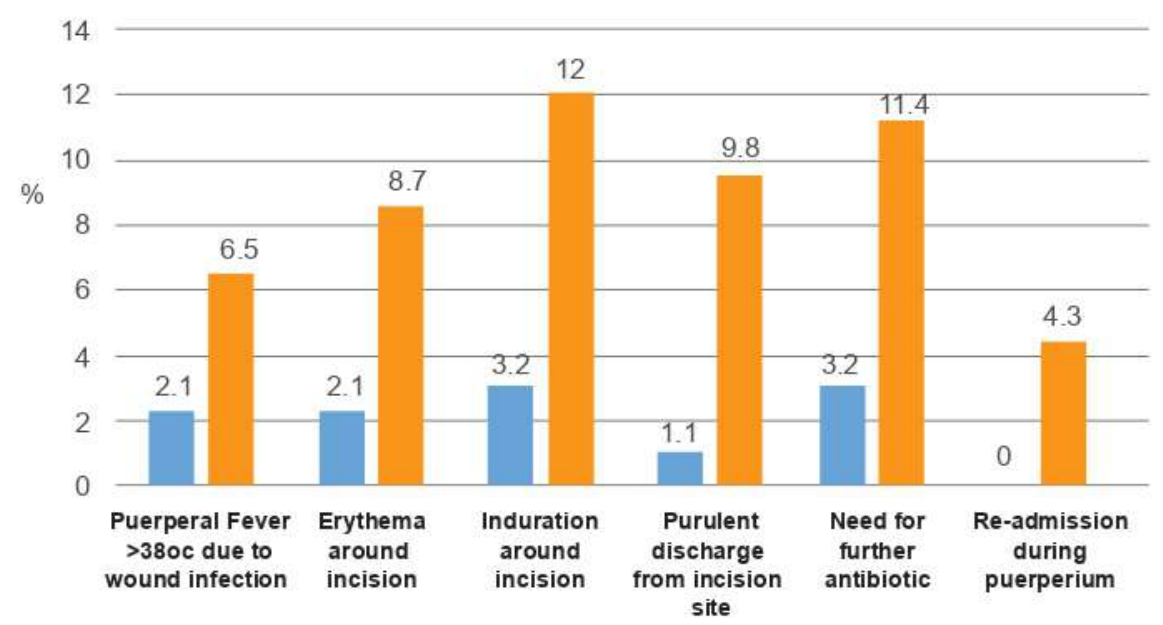

Table 1: Socio-demographic \& obstetric data among studied groups.

\begin{tabular}{|c|c|c|c|}
\hline & $\begin{array}{l}\text { Test group } \\
\mathrm{N}=94(\%)\end{array}$ & $\begin{array}{c}\text { Control group } \\
\mathbf{n}=92(\%)\end{array}$ & Test of significance \\
\hline $\begin{array}{l}\text { Age/years } \\
\text { Mean } \pm \text { SD }\end{array}$ & $27.44 \pm 5.06$ & $27.59 \pm 4.97$ & $\begin{array}{l}\mathrm{t}=0.22 \\
\mathrm{P}=0.83\end{array}$ \\
\hline $\begin{array}{ll}\text { Gravidity } \\
\text { - } & \text { Primigravida } \\
- & 2^{\text {nd }} \\
- & 3^{\text {rd }} \\
- & >3\end{array}$ & $\begin{array}{l}12(12.8) \\
14(14.9) \\
34(36.2) \\
34(36.2)\end{array}$ & $\begin{array}{l}13(14.1) \\
16(17.4) \\
31(33.7) \\
32(34.8)\end{array}$ & $\begin{array}{l}\chi^{2}=0.35 \\
\mathrm{p}=0.95\end{array}$ \\
\hline $\begin{array}{ll}\text { Parity } \\
\text { - } & \text { Nullipara } \\
\text { - } & \text { Primipara } \\
\text { - } & 2^{\text {nd }} \\
\text { - } & \geq 3\end{array}$ & $\begin{array}{l}12(12.8) \\
18(19.1) \\
38(40.4) \\
26(27.7)\end{array}$ & $\begin{array}{l}13(14.1) \\
19(20.7) \\
41(44.6) \\
19(20.7)\end{array}$ & $\begin{array}{l}\chi^{2}=1.25 \\
p=0.74\end{array}$ \\
\hline $\begin{array}{l}\text { Gestational age/weeks } \\
\text { Mean } \pm \text { SD }\end{array}$ & $39.15 \pm 0.98$ & $39.13 \pm 0.99$ & $\begin{array}{l}\mathrm{t}=0.13 \\
\mathrm{p}=0.89\end{array}$ \\
\hline $\begin{array}{l}\text { Mode of previous deliveries : } \\
\text { - Vaginal } \\
\text { - Cesarean }\end{array}$ & $\begin{array}{c}8(9.8) \\
74(90.2)\end{array}$ & $\begin{array}{c}3(3.7) \\
78(96.3)\end{array}$ & $\begin{array}{l}\chi^{2}=2.37 \\
\mathrm{p}=0.12\end{array}$ \\
\hline
\end{tabular}

$\chi^{2}$ :Chi-Square test $\mathrm{t}$ : Student t test *statistically significant $\mathrm{p}$ : probability of error 
Table 2: Maternal and fetal condition during labor among studied groups.

\begin{tabular}{|l|c|c|c|}
\hline & $\begin{array}{c}\text { Test group } \\
\mathbf{N = 9 4 ( \% )}\end{array}$ & $\begin{array}{c}\text { Control group } \\
\mathbf{n = 9 2 ( \% )}\end{array}$ & Test of significance \\
\hline $\begin{array}{l}\text { Current Cs } \\
\text { Non-elective }\end{array}$ & $94(100.0)$ & $92(100.0)$ & \\
\hline Previous CS & $74(78.7)$ & $78(96.3)$ & $\begin{array}{c}\chi^{2}=2.37 \\
\mathrm{p}=0.12\end{array}$ \\
\hline Breech presentation & $4(4.3)$ & $2(2.2)$ & $\begin{array}{c}\text { FET } \\
\mathrm{P}=0.68\end{array}$ \\
\hline Labor pain & $85(90.4)$ & $85(92.4)$ & $\begin{array}{c}\chi^{2}=0.23 \\
\mathrm{P}=0.63\end{array}$ \\
\hline Acute fetal distress & $2(2.1)$ & $3(3.3)$ & $\begin{array}{c}\text { FET } \\
\mathbf{P}=\mathbf{0 . 6 8}\end{array}$ \\
\hline Rupture membrane & $27(28.7)$ & $23(25.0)$ & $\begin{array}{c}\chi^{2}=0.57 \\
\mathrm{P}=0.62\end{array}$ \\
\hline Anesthesia(spinal) & $94(100.0)$ & $92(100.0)$ & \\
\hline
\end{tabular}

$\chi^{2}$ :Chi-Square test FET: Fischer exact test *statistically significant p: probability of error

Table 3: Comparison between endometritis, wound infection needing antibiotic and re-admission during puerperium among studied groups.

\begin{tabular}{|l|c|c|c|}
\hline & $\begin{array}{c}\text { Test group } \\
\mathbf{N}=\mathbf{9 4}(\%)\end{array}$ & $\begin{array}{c}\text { Control group } \\
\mathbf{n = 9 2 ( \% )}\end{array}$ & Test of significance \\
\hline $\begin{array}{l}\text { Endometritis } \\
\text { needing antibiotic }\end{array}$ & $4(4.3)$ & $15(16.3)^{\#}$ & $\begin{array}{c}\chi^{2}=7.36 \\
\mathrm{p}=0.006^{*}\end{array}$ \\
\hline $\begin{array}{l}\text { Wound infection needing } \\
\text { antibiotics }\end{array}$ & $3(3.2)$ & $11(11.9)^{\mathrm{s}}$ & $\begin{array}{l}\chi^{2}=5.13 \\
\mathrm{p}=0.02^{*}\end{array}$ \\
\hline $\begin{array}{l}\text { Re-admission during puer- } \\
\text { perium }\end{array}$ & $0(0.0)$ & $6(6.5)$ & $\begin{array}{l}\chi^{2}=6.34 \\
\mathrm{p}=0.01^{*}\end{array}$ \\
\hline
\end{tabular}

\#of them 2 cases with pelvic collections \& need surgical intervention

$\$: 4$ of them need also admission for 2 weeks

$\chi^{2}$ :Chi-Square test *statistically significantp: probability of error 
Table 4: Endometritis distribution among studied groups.

\begin{tabular}{|c|c|c|c|}
\hline Endometritis & $\begin{array}{l}\text { Test group } \\
\mathrm{N}=94(\%)\end{array}$ & $\begin{array}{c}\text { Control group } \\
\mathbf{n}=92(\%)\end{array}$ & $\begin{array}{c}\text { Test of } \\
\text { significance }\end{array}$ \\
\hline Puerperal Fever $>38^{\circ} \mathrm{c}$ due to endometritis & $4(4.3)$ & $14(15.2)$ & $\begin{array}{l}\chi^{2}=6.39 \\
\mathrm{p}=0.01^{*}\end{array}$ \\
\hline Uterine Tenderness & $3(3.2)$ & 11(11.9) & $\begin{array}{l}\chi 2=5.13 \\
\mathrm{p}=0.02^{*}\end{array}$ \\
\hline Abdominal Pain & $1(1.1)$ & 13(14.1) & $\begin{array}{c}\chi^{2}=11.41 \\
\mathrm{p}=0.0007^{*}\end{array}$ \\
\hline Offensive Vaginal discharge & $2(2.1)$ & $12(13.0)$ & $\begin{array}{l}\chi^{2}=7.96 \\
\mathrm{p}=0.004^{*}\end{array}$ \\
\hline Purulent drainage from uterus & $2(2.1)$ & $9(9.8)$ & $\begin{array}{l}\chi^{2}=4.89 \\
\mathrm{p}=0.02\end{array}$ \\
\hline $\begin{array}{l}\text { WBCs at } 7 \text { th day postpartum(K/UL) } \\
\text { mean } \pm \text { SD }\end{array}$ & $10.08 \pm 2.42$ & $11.54 \pm 3.82$ & $\begin{array}{c}\mathrm{t}=3.13 \\
\mathrm{p}=0.002 *\end{array}$ \\
\hline Need for further antibiotic during puerperium & $4(4.3)$ & $15(16.3)$ & $\begin{array}{l}\chi^{2}=7.36 \\
p=0.006^{*}\end{array}$ \\
\hline Re-admission during puerperium & $0(0.0)$ & $2(2.2)$ & $\begin{array}{c}\text { FET } \\
\mathrm{P}=0.24\end{array}$ \\
\hline
\end{tabular}

$\chi^{2}$ :Chi-Square test ${ }^{*}$ statistically significant FET: Fischer exact test

p: probability of error

Table 5: Wound infection distribution among studied groups.

\begin{tabular}{|c|c|c|c|}
\hline Wound infection & $\begin{array}{l}\text { Test group } \\
\mathrm{N}=94(\%)\end{array}$ & $\begin{array}{c}\text { Control group } \\
\mathbf{n}=92(\%)\end{array}$ & Test of significance \\
\hline Puerperal fever $>38^{\circ} \mathrm{c}$ due to wound infection & $2(2.1)$ & $6(6.5)$ & $\begin{array}{l}\chi^{2}=2.18 \\
\mathrm{P}=0.13\end{array}$ \\
\hline Erythema around incision & $2(2.1)$ & $8(8.7)$ & $\begin{array}{l}\chi^{2}=3.94 \\
\mathrm{P}=0.04 *\end{array}$ \\
\hline Induration around incision & $3(3.2)$ & $11(12.0)$ & $\begin{array}{l}\chi^{2}=5.13 \\
\mathrm{P}=0.02 *\end{array}$ \\
\hline Purulent discharge from incision site & $1(1.1)$ & $9(9.8)$ & $\begin{array}{l}\chi^{2}=6.95 \\
\mathrm{P}=0.008^{*}\end{array}$ \\
\hline $\begin{array}{l}\text { WBCs at } 7 \text { th day postpartum(K/UL) } \\
\text { mean } \pm \text { SD }\end{array}$ & $10.08 \pm 2.42$ & $11.54 \pm 3.82$ & $\begin{array}{c}\mathrm{t}=3.13 \\
\mathrm{p}=0.002 *\end{array}$ \\
\hline Need for further antibiotic during puerperium & $3(3.2)$ & 11(11.9) & $\begin{array}{l}\chi^{2}=5.13 \\
\mathrm{P}=0.02 *\end{array}$ \\
\hline Post-operative hospital stay(48 hours) & $94(100.0)$ & $92(100.0)$ & \\
\hline Re-admission during puerperium & $0(0.0)$ & $4(4.3)$ & $\begin{array}{c}\text { FET } \\
\mathrm{P}=0.057\end{array}$ \\
\hline
\end{tabular}

$\chi^{2}$ :Chi-Square test ${ }^{*}$ statistically significantFET: Fischer exact test p: probability of error 
Table 6: Neonatal Outcome distribution among studied groups..

\begin{tabular}{|c|c|c|c|}
\hline Neonatal Outcome & $\begin{array}{l}\text { Test group } \\
\mathrm{N}=94(\%)\end{array}$ & $\begin{array}{c}\text { Control group } \\
\mathbf{n}=92(\%)\end{array}$ & $\begin{array}{c}\text { Test of } \\
\text { significance }\end{array}$ \\
\hline Death & $0(0.0)$ & $0(0.0)$ & \\
\hline NICU admission & $11(11.7)$ & $13(14.1)$ & $\begin{array}{l}\chi^{2}=0.24 \\
\mathrm{P}=0.62\end{array}$ \\
\hline $\begin{array}{l}\text { Causes of NICU admission } \\
\text { Meconium aspiration } \\
\text { Jaundice }\end{array}$ & $\begin{array}{c}n=11 \\
4(36.4) \\
7(63.6)\end{array}$ & $\begin{array}{c}\mathrm{n}=13 \\
5(38.5) \\
8(61.5)\end{array}$ & $\begin{array}{l}\chi^{2}=0.01 \\
P=0.91\end{array}$ \\
\hline Respiratory distress & $2(2.1)$ & $3(3.3)$ & $\begin{array}{c}\text { FET } \\
\mathrm{P}=0.68\end{array}$ \\
\hline Necrotizing enterocolitis & 0 & 0 & \\
\hline
\end{tabular}

$\chi^{2}$ :Chi-Square test FET: Fischer exact test p: probability of error 